\title{
PENERAPAN MODEL PEMBELAJARAN INOVATIF TIPE INKUIRI UNTUK MENINGKATKAN AKTIVITAS DAN HASIL BELAJAR ILMU BANGUNAN GEDUNG SISWA KELAS X PROGRAM KEAHLIAN TEKNIK GAMBAR BANGUNAN SMK NEGERI 1 BALIGE
}

\author{
Omri Guinnes Simajuntak ${ }^{1}$, Rachmat Mulyana ${ }^{2}$ \\ ${ }^{1}$ Alumni Program Studi Pendidikan Teknik Bangunan, Fakultas Teknik UNIMED \\ ${ }^{2}$ Dosen Pengajar Jurusan Pendidikan Teknik Bangunan, Fakultas Teknik UNIMED \\ (rahmat.mulyana10@gmail.com)
}

\begin{abstract}
ABSTRAK
Penelitian ini bertujuan untuk meningkatkan aktivitas dan hasil belajar Ilmu Bangunan Gedung siswa kelas X program keahlian Teknik Gambar Bangunan SMK Negeri 1 Balige melalui model pembelajaran Inkuiri. Penelitian ini merupakan penelitian tindakan kelas dengan Subjek penelitian siswa kelas X Program Keahlian Teknik Gambar Bangunan yang dilakukan pada semester ganjil tahun pelajaran 2015/2016. Dari data observasi aktivitas siswa menunjukkan adanya peningkatan aktivitas belajar siswa dari siklus I ke siklus II. yaitu pada siklus I yang mendapat nilai dalam kategori sangat aktif 8 siswa (26,67\%), kategori aktif 10 siswa (33,33\%), kategori cukup aktif 12 siswa $(40 \%)$ dan kategori tidak aktif tidak ada $(0 \%)$. Sedangkan pada siklus II yang mendapat nilai kategori sangat aktif 17 siswa (56,67\%), kategori aktif 11 siswa (36,66\%), kategori cukup aktif 2 siswa $(6,67 \%)$ dan tidak aktif tidak ada, dan data hasil belajar siswa menunjukkan adanya peningkatan nilai hasil belajar siswa dari siklus I ke siklus II. Hai ini dapat dilihat pada siklus I yang mendapat nilai dalam kategori sangat kompeten tidak ada $(0 \%)$, kategori kompeten 5 siswa $(16,67 \%)$, kategori cukup kompeten 25 siswa $(83,33 \%)$ dan kategori tidak kompeten tidak ada. Sedangkan pada siklus II yang mendapat nilai dalam kategori sangat kompeten 16 siswa (53,33\%), kategori kompeten 12 siswa $(40 \%)$, kategori cukup kompeten 2 siswa (6,67\%). Berdasarkan hasil penelitian bahwa dengan menerapkan model pembelajaran Inkuiri dapat: Meningkatkan aktivitas belajar dan hasil belajar Ilmu Bangunan Gedung siswa kelas X program keahlian Teknik Gambar Bangunan SMK Negeri 1 Balige.
\end{abstract}

Kata Kunci :Model Pembelajaran Inovatif, Inkuiri, Aktivitas, Hasil Belajar

\begin{abstract}
This research aims to improve the activity and learning outcomes Science Building class X Architecture Engineering skills program SMK 1 Balige through inquiry learning model. This research is a classroom action research subject class X Architecture Engineering Expertise Program conducted in the first semester of the school year 2015/2016. From the observation data shows an increase in the activity of student learning activities of students from the first cycle to the second cycle. namely in the first cycle who scored in the category of very active 8 students (26.67\%), active category 10 students (33.33\%), moderately active category of 12 students $(40 \%)$ and inactive categories none $(0 \%)$, While on the second cycle that gets the value of the category of very active 17 students $(56.67 \%)$, active category 11 students (36.66\%), moderately active category 2 students $(6.67 \%)$ and inactive non-existent, and the result data study students showed an increase in the value of learning outcomes of students from the first cycle to the second cycle. Hi can be seen in the first cycle who scored in the category of very competent none (0\%), competent category 5 students $(16.67 \%)$, category competent enough 25 students $(83.33 \%)$ and the category of incompetent no. While on the second cycle who scored in the category of very competent 16 students $(53.33 \%)$, the category of competent 12 students (40\%), category 2 students competent enough (6.67\%). Based on research results that by applying inquiry learning model can:
\end{abstract}




\section{Penerapan Model Pembelajaran Inovatif Tipe Inkuiri Untuk Meningkatkan Aktivitas dan Hasil Belajar Ilmu Bangunan Gedung Siswa Kelas x Program Keahlian Teknik Gambar Bangunan SMK Negeri 1 Balige}

Improve learning activities and learning outcomes Science Building class X Architecture Engineering skills program SMK 1 Balige.

Keywords: Innovative Learning Model, Inquiry, Activities, Learning Outcomes

\section{Pendahuluan}

Pendidikan merupakan usaha sadar dan terencana untuk mewujudkan suasana belajar dan proses pembelajaran agar peserta didik secara aktif mengembangkan potensi dirinya untuk memiliki kekuatan spritual keagamaan, pengendalian diri, kepribadian, kecerdasan, akhlak mulia, serta keterampilan yang diperlukan dirinya, masyarakat, bangsa dan Negara. Tujuan dari pendidikan sendiri adalah mengembangkan potensi peserta didik agar menjadi manusia yang beriman dan bertakwa kepada Tuhan Yang Maha Esa, berakhlak mulia, sehat, berilmu, kreatif, mandiri, dan menjadi warga Negara yang demokratis serta bertanggung jawab.

Untuk mengembangkan potensi peserta didik dilakukan pendidikan formal, pendidikan formal dilakukan oleh lembaga pendidikan seperti SMA, SMK dan lain-lain. Di lembaga sekolah proses pembelajaran dilakukan untuk mencapai tujuan pendidikan nasional. Siswa di lembaga sekolah melakukan aktivitas belajar dimana belajar dilakukan secara sadar dengan didukung oleh guru, media pembelajaran, fasilitas sekolah dan lain-lain. Melalui aktivitas belajar terjadi perubahan perilaku dalam ranah kognitif, afektif, dan psikomotorik..

SMK Negeri 1 Balige adalah salah satu lembaga pendidikan formal yang menyiapkan lulusannya untuk diharapkan mampu memasuki dan bersaing di dunia usaha dan industri. Terdapat beberapa jurusan yang ada di sekolah ini, salah satunya adalah Teknik Bangunan.

Tabel 1. Perolehan Nilai Hasil Belajar 1 Tahun Terakhir Mata Diklat Ilmu Bangunan Gedung Kelas X Program Keahlian Teknik Gambar Bangunan SMK Negeri 1 Balige.

\begin{tabular}{cccc}
$\begin{array}{c}\text { Tahun } \\
\text { Pelajaran }\end{array}$ & $\begin{array}{c}\text { Kelas } \\
\text { Interval }\end{array}$ & Fo & Fr \\
\hline
\end{tabular}

\begin{tabular}{|c|c|c|c|}
\hline \multirow{4}{*}{$2013 / 2014$} & $<70$ & 4 & 13,34 \\
\hline & 70-79 & 20 & 66,66 \\
\hline & $80-89$ & 6 & 20 \\
\hline & $90-100$ & - & - \\
\hline \multicolumn{2}{|c|}{ Jumlah : } & 30 & 100,00 \\
\hline
\end{tabular}

Kenyataannya, kemampuan dan keterampilan mata diklat Ilmu Bangunan Gedung (IBG) dari siswa kelas X Program Keahlian Teknik Gambar Bangunan SMK Negeri 1 Balige sekarang ini masih jauh dari yang diharapkan. Hal ini dapat dilihat dari hasil observasi di SMK Negeri 1 Balige $n$ Daftar Kumpulan Nilai (DKN), p menemukan bahwa hasil belajar siswa kelas $X$ Program Keahlian Teknik Gambar Bangunan SMK Negeri 1 Balige Tahun Ajaran 2013/2014 pada semester genap bahwa dari 30 siswa, yang memperoleh nilai $<70$ sebanyak $13,34 \%$, nilai 70-79 sebanyak 66,66\%, nilai 80-89 sebanyak 20\%, dan nilai 90-100 tidak ada, dengan Kriteria Ketuntasan Minimum (KKM) yang berlaku di sekolah SMK Negeri 1 Balige tersebut sebesar 70.

Faktor yang sangat mempengaruhi hasil belajar adalah kurangnya ketertarikan siswa untuk mengikuti pelajaran IBG, karena metode yang paling sering digunakan oleh guru mata pelajaran diklat IBG adalah metode ceramah atau komunikasi verbal, padahal metode ini membuat guru lebih mendominasi kegiatan belajar dalam kelas.

Dengan melihat adanya keterkaitan yang erat antara model pembelajaran inkuiri dan aktivitas belajar dengan hasil belajar IBG, maka peneliti tertarik untuk mengetahui lebih jauh dan melakukan penelitian ini.

\section{Kajian Pustaka}

2.1 Hakekat aktivitas Belajar

Aktivitas merupakan prinsip atau asas yang sangat penting di dalam interaksi belajarmengajar. Tanpa aktivitas kegiatan belajar mengajar tidak mungkin dapat berlangung dengan baik. Menurut Slameto (2003:54), faktor-faktor yang mempengaruhi hasil belajar 
adalah (1) Faktor-faktor internal, (2) Faktorfaktor eksternal. Faktor-faktor internal terdiri dari faktor jasmaniah (kesehatan, cacat tubuh), faktor psikologis (intelegensi, perhatian, minat, bakat, motif, kematangan, kesiapan), dan faktor kelelahan. Sedangkan faktor-faktor eksternal terdiri dari faktor keluarga (cara orang tua mendidik, relasi antar anggota keluarga, suasana rumah, keadaan ekonomi keluarga, pengertian orang tua, latar belakang kebudayaan), faktor sekolah (metode mengajar, kurikulum, relasi guru dengan siswa, disiplin sekolah, alat pelajaran, waktu sekolah, standar pelajaran di atas ukuran, keadaan gedung, metode belajar, tugas rumah), dan faktor masyarakat (kegiatan siswa dalam masyarakat, media massa, teman bergaul, bentuk kehidupan masyarakat).

Dari pendapat di atas, dapat disimpulkan bahwa faktor-faktor yang mempengaruhi hasil belajar siswa adalah faktor internal siswa antara lain kemampuan yang dimiliki siswa tentang materi yang akan disampaikan, sedangkan faktor eksternal antara lain model pembelajaran yang digunakan guru di dalam proses pembelajaran.

\subsection{Hakikat Metode Pembelajaran Inkuiri}

Model pembelajaran adalah suatu perencanaan atau suatu pola yang digunakan sebagai pedoman dalam merencanakan pembelajaran di kelas atau pembelajaran dalam tutorial dan untuk menentukan perangkatperangkat pembelajaran termasuk didalamnya buku-buku, film,komputer, dan lain-lain (Joyce, 1992: 4).

Menurut Moh Uzer Usman, dkk, (1993:126) adapun langkah-langkah yang dapat digunakan dalam penggunaan pembelajaran Inkuiri dalam proses belajar mengajar adalah sebagai berikut :

a. Membina suasana yang responsif diantara siswa

b. Mengemukakan permasalahan untuk diInkuiri (ditemukan).

c. Mengajukan pertanyaan-pertanyaan kepada siswa.

d. Merumuskan hipotesis. (Asumsi atau prakiraan yang merupakan jawaban dari permasalahan tersebut).

e. Menguji hipotesis. Guru mengajukan pertanyaan yang sifatnya meminta data untuk pembuktian hipotesis f. Pengambilan kesimpulan. Perumusan kesimpulan ini dilakukan antara guru dan siswa.

\subsection{Peningkatan Aktivitas Siswa Belajar IBG melalui Penerapan Model Pembelajaran Inkuiri}

Dalam meningkatkan aktivitas siswa untuk mata diklat IBG, dalam pembelajarannya harus menarik sehingga siswa dapat termotivasi untuk belajar. Untuk itu sangat diperlukan model pembelajaran yang tidak membosankan bagi siswa, dimana siswa dituntut untuk jauh lebih aktif dibandingkan guru.

Model pembelajaran inkuiri adalah model pembelajaran yang melibatkan siswa secara aktif baik pikiran, pendengaran, pengelihatan, dan psikomotor dalam proses belajar mengajar. Karena model pembelajaran inkuiri menekankan kepada aktivitas siswa secara maksimal untuk mencari dan menemukan. Artinya model pembelajaran inkuiri menempatkan siswa sebagai subjek belajar.

\subsection{Peningkatan Hasil Belajar IBG melalui Penerapan Model Pembelajaran Inkuiri Siswa Kelas X Program Keahlian Teknik Gambar Bangunan \\ Hasil belajar adalah segala kemampuan} yang dicapai oleh siswa melalui proses belajar yang berupa pemahaman, penerapan pengetahuan dan keterampilan yang berguna bagi siswa dalam kehidupannya seharihari,serta sikap dan cara berpikir kritis dan analitis dalam mewujudkan manusia yang berkualitas dan bertanggung jawab.

Adapun model pembelajaran yang tepat untuk kondisi tersebut agar minat dan hasil belajar siswa meningkat adalah model pembelajaran inkuiri.

Dengan model pembelajaran inkuiri, diharapkan dapat meningkatkan hasil belajar IBG pada materi macam-macam jenis pondasi dan penggunaan pondasi dan ketentuan umum ukuran pondasi pada siswa kelas $X$ Program Keahlian Teknik Gambar Bangunan SMK Negeri 1 Balige.

\subsection{Hipotesis Penelitian}

Berdasarkan kajian teori dan kerangka berpikir yang telah diuraikan di atas, maka penelitian ini direncanakan terbagi kedalam 2 (dua) siklus, setiap siklus dilaksanakan mengikuti 


\section{Penerapan Model Pembelajaran Inovatif Tipe Inkuiri Untuk Meningkatkan Aktivitas dan Hasil Belajar Ilmu Bangunan Gedung Siswa Kelas x Program Keahlian Teknik Gambar Bangunan SMK Negeri 1 Balige}

prosedur perencanaan (planning), tindakan (acting), pengamatan (observing), dan refleksi (reflecting).

Dengan demikian dapat diduga bahwa:

a. Dengan menerapkan model pembelajaran Inkuiri dapat meningkatkan aktivitas siswa dalam mata diklat IBG siswa kelas $X$ Program Keahlian Teknik Gambar Bangunan SMK Negeri 1 Balige

b. Dengan menerapkan model pembelajaran Inkuiri dapat meningkatkan hasil belajar siswa pada mata diklat IBG siswa kelas $X$ Program Keahlian Teknik Gambar Bangunan SMK Negeri 1 Balige.

\section{Metodologi Penelitian}

Penelitian ini dilaksanakan di SMK Negeri 1 Balige, Jln. Tarutung No. 1 Kec. Balige Kab. Toba Samosir. Penelitian ini dilaksanakan pada bulan Februari Tahun Ajaran 2015/2016.

Subjek dalam penelitian ini adalah siswa kelas X Program Keahlian Teknik Gambar Bangunan tahun pelajaran 2014/2015, yaitu sebanyak 1 kelas yang terdiri dari 30 siswa. Dan yang menjadi objek dari penelitian ini adalah hasil belajar Ilmu Bangunan Gedung.

Penelitian ini dilaksanakan dalam 2 siklus untuk siklus I diselesaiakan dalam 2 kali pertemuan dan untuk siklus II diselesaikan dengan 2 kali pertemuan,dimana dalam 1 siklus terdiri dari 4 tahapan, yaitu : (1) perencanaan (planning), (2) tindakan (acting), (3) pengamatan (observing), dan (4) refleksi (reflecting) Arikuntoro (2008).

\subsection{TeknikPengumpulan Data}

\subsubsection{TeknikPengumpulan Data}

Observasi dilakukan untuk mengetahui aktivitas siswa selama proses pembelajaran. Paul B. Diedric (dalam Sardiman, 2011:101) yang menggolongkan aktivitas belajar dalam delapan jenis, diantaranya visual activities, oral activities,listening activities, writing activities, drawing activities, motor activities, mental activities dan emotional activities. Dalam penelitian ini, aktivitas yang dinlai hanya yang dianggap perlu pada mata pelajaran IBG. Hal ini disebabkan karena keterbatasan waktu dan penulisannya.

\subsubsection{Tes}

Tes menggunakan bentuk pilihan berganda, yang terdiri dari 4 pilihan. Setiap pilihan mempunyai 1 jawaban benar dan 3 pengecoh. Setiap butir soal yang dijawab benar diberi nilai 1 dan untuk jawaban yang salah diberi nilai 0 .

\subsection{Uji Coba Instrumen}

Uji coba instrumen penelitian ini dilakukan pada siswa kelas XI Program Keahlian Teknik Gambar Bangunan SMK Negeri 1 Balige. Uji coba ini bertujuan untuk mendapatkan alat ukur yang benar-benar dapat menjaring data yang akurat agar kesimpulan yang diambil sesuai dengan kenyataan. Uji coba ini dilakukan untuk mengetahui nilai validitas, reliabilitas, tingkat kesukaran dan daya pembeda dari instrumen tersebut.

\subsubsection{Validitas Butir Tes}

Uji validitas pada dasarnya merupakan salah satu upaya untuk memperoleh tes yang baik. Ada beberapa jenis validitas yang dikenal, namun uji validitas yang dilakukan dalam kegiatan ini meliputi uji validitas isi (content) dan validitas konstruksi. Uji validitas ini dilakukan dengan menyusun soal yang dimaksud untuk mengatur tujuan tertentu sesuai dengan materi yang diajarkan, sehingga diyakini bahwa tes yang disusun sesuai dengan materi yang diajarkan atau dengan kata lain bahwa tes yang dibuat benar-benar mengukur apa yang diukur.

Untuk mengukur validitas hasil belajar diuji dengan menggunakan rumus koefisien. Validitas tes digunakan teknik Point Biserial (Arikunto, 2009) dengan rumus:

$$
\gamma_{\mathrm{pbi}}=\frac{M_{p}-M_{t}}{S_{t}} \sqrt{\frac{p}{q}}
$$

Keterangan :

$\gamma_{\mathrm{pbi}}=$ Koefisien korelasi biserial

$\mathrm{Mp}=$ Rerata skor subjek yang menjawab

betul bagi item yang dicari validitasnya.

$\mathrm{Mt}=$ Rerata skor total

St $=$ Standar deviasi dari skor total

$\mathrm{p}=$ proporsi siswa yang menjawab benar

$\mathrm{q}=$ proporsi siswa yang menjawab salah 
Kemudian harga Ypbi dikonsultasikan dengan harga $r_{\text {tabel }}$ pada taraf signifikan $5 \%$. Apabila $\gamma_{p b i}>r_{\text {tabel }}$ maka butir tes tersebut valid dan begitu juga sebaliknya. Dari hasil uji instrumen diperoleh nilai validitas soal pada siklus I dari 25 butir item yang disediakan, terdapat 4 butir soal yang tidak valid yaitu nomor 2, 4, 9, dan 23. Sedangkan pada siklus II dari 25 butir yang disediakan, terdapat 5 butir yang tidak valid yaitu nomor 8, 11, 16, 24 dan 25.

\subsubsection{Uji Tingkat Kesukaran}

Butir tes yang baik adalah butir tes yang tidak terlalu mudah dan tidak terlalu susah. Jika terlalu mudah, maka peserta tes tidak termotivasi untuk mempertinggi usaha untuk memecahkan masalahnya, sebaliknya jika terlalu sukar, menyebabkan siswa menjadi putus asa dan tidak bersemangat untuk mencoba lagi karena di luar jangkauan. Angka yang menunjukkan tingkat kesukaran suatu butir tes disebut Indeks Kesukaran Item (Arikunto, 2009), dapat dihitung dengan rumus:

$$
P=\frac{B}{J S}
$$

Keterangan :

$\mathrm{P}=$ Indeks kesukaran

$\mathrm{B}=$ Jumlah peserta tes yang menjawab benar

JS= Jumlah seluruh peserta tes

Semakin besar harga $\mathrm{P}$ maka item tersebut semakin mudah, sebaliknya semakin kecil item tersebut semakin sulit. Suatu butir tes dikatakan memenuhi syarat jika harga $P$ berkisar antara : 0,20-0,80, jika $\mathrm{P}<0,20$ berarti butir tes terlalu sulit, dan jika $\mathrm{P}>0,80$ berarti butir tes terlalu mudah. Dari hasil uji instrumen yang telah dilakukan dari 25 butir item siklus I terdapat 12 butir kategori mudah dan 13 butir kategori sedang. Sedangkan pada siklus II dari 25 butir item terdapat 6 butir kategori mudah dan 19 butir kategori sedang.

\subsubsection{Uji Daya Pembeda}

Perhitungan Indeks Daya Pembeda setiap butir tes dilakukan dengan Rumus
Dieddrich ynag dikemukan Arikunto (2009) sebagai berikut :

$$
\mathrm{D}=\frac{B_{A}}{J_{A}}-\frac{B_{B}}{J_{B}}
$$

Keterangan :

$\mathrm{D}=$ Daya pembeda butir soal

$\mathrm{B}=$ Banyaknya kelompok atas yang menjawab benar

$\mathrm{J}_{\mathrm{A}}=$ Banyaknya subjek kelompok atas

$\mathrm{B}_{\mathrm{B}}=$ Banyaknya kelompok bawah yang menjawab benar

$\mathrm{J}_{\mathrm{B}}=$ Banyaknya subjek kelompok bawah

Hasil perhitungan indeks daya pembeda dikonsultasikan dengan ketentuan yang dikemukan oleh Arikunto, yaitu:

$$
\begin{aligned}
& \text { D : } 0,00-0,20 \rightarrow \text { butir soal jelek } \\
& \text { D : } 0,21-0,40 \rightarrow \text { butir soal cukup } \\
& \text { D : } 0,41-0,70 \rightarrow \text { butir soal baik } \\
& \text { D : } 0,71-1,00 \rightarrow \text { butir soal baik sekali }
\end{aligned}
$$

Dari hasil uji instrumen yang telah dilakukan pada siklus I dari 25 butir yang disediakan 5 butir soal dalam kategori baik yaitu nomor 10, 12, 15, 19, dan 24.10 butir soal dalam kategori cukup yaitu nomor 1 , $3,5,6,7,8,17,21,22$, dan 25. Dan 10 butir soal dalam kategori baik yaitu nomor 6 dan 17. 7 butir soal dalam kaegori cukup yaitu nomor 3, 9, 12, 15, 22, 23, dan 25. 16 butir soal dalam kategori jelek yaitu nomor $1,2,4,5,7,8,10,11,13,14,16,18,19,20$, 21, dan 24 .

\subsubsection{Uji Reliabilitas}

Uji reliabilitas tes yang akan digunakan dalam pengujian ini adalah dengan menggunakan rumus K-R. 20 (Arikunto, 2009), yaitu:

$$
\mathrm{r}_{11}=\left[\frac{n}{n-1}\right]\left[\frac{S^{2}-\sum p q}{S^{2}}\right]
$$

\footnotetext{
Keterangan;

$\mathrm{r}_{11}=\quad$ Reliabilitas tes secara keseluruhan $\mathrm{p}=$ Proporsi siswa yang menjawab benar

$\mathrm{q}=$ Proporsi siswa yang menjawab salah $(q=1-p)$
} 
$\Sigma \mathrm{pq}=$ Jumlah hasil perkalian antara $\mathrm{p}$ dan $\mathrm{q}$

$\mathrm{n}=\quad$ Banyaknya item

$\mathrm{S}=\quad$ Standar deviasi dari tes

Besar $r_{11}$ yang diperoleh dikonsuktasikan dengan indeks korelasi yang dikemukakan Arikunto:

- Antara $0,800 \mathrm{~s} / \mathrm{d} 1,000$ tergolong sangat tinggi

- Antara 0,600 s/d $<00,790$
tergolong tinggi
- Antara 0,400 s/d
tergolong cukup
- Antara 0,200 s/d $<0,599$
tergolong rendah
- Antara 0,000 s/d
tergolong sangat rendah

Dari hasil uji instrumen yang telah dilakukan, harga reliabilitas tes Ilmu Bangunan Gedung pada siklus I harga $r_{11}$ 0,60 dan kategori sedang pada siklus II harga $r_{11} 0,42$.

\subsection{Teknik Analisis Data}

Data yang dikumpulkan pada setiap kegiatan dari pelaksanaan siklus penelitian adalah data kuantitatif yang merupakan nilai hasil belajar siswa.

$$
\text { DS }=\frac{\text { Skor yang diperoleh siswa }}{\text { Skor Maksimal }} \times 100 \%
$$

Dengan Kriteria:

$<70$ : Siswa belum tuntas

$\geq 70$ : Siswa telah tuntas dalam belajar

Ketuntasan Klasikal, Persentase siswa yang telah tuntas belajar secara klasikal dapat diketahui dengan rumus(Arikunto, 2008):

$$
\mathrm{D}=\frac{X}{N} x 100 \%
$$

Keterangan:

$\mathrm{D}=$ Persentase Ketuntasan Belajar Klasikal $X=$ Jumlah Siswa yang telah tuntas belajar $\mathrm{N}=$ Jumlah Seluruh Siswa

Berdasarkan kriteria ketuntasan belajar, jika dalam kelas tersebut terdapat $85 \%$ siswa yang telah mencapai persentase nilai $\geq 70$ maka ketuntasan belajar secara keseluruhan telah tercapai.

\section{Hasil dan Pembahasan Penelitian}

Hasil dan pembahasan penelitian diuraikan dalam tahapan-tahapan yang berupa siklus-siklus pembelajaran yang dilakukan dalam proses belajar mengajar di dalam kelas. Dalam penelitian ini pembelajaran dilakukan dalam dua siklus sebagaimana pemaparan berikut ini :

\subsection{Siklus I}

Siklus pertama terdiri dari empat tahap, yaitu perencanaan, pelaksanaan, observasi dan refleksi, seperti berikut ini:

\subsubsection{Perencanaan}

a. Melakukan analisis kurikulum untuk mengetahui kompetensi dasar yang akan disampaikan kepada siswa dengan menggunakan pembelajaran Inkuiri.

b. Membuat rencana pembelajaran Inkuiri

c. Membuat lembar kerja siswa

d. Membuat instrumen yang digunakan dalam siklus PTK

e. Menyusun alat evaluasi pembelajaran

\subsubsection{Pelaksanaan}

Dalam setiap siklus dilaksanakan dengan durasi waktu $2 \times 45$ menit. Pada siklus pertama, pertemuan ini diawali dengan sub materi Instalasi Pipa PVC. Pembelajaran dilakukan dalam tiga tahap, yaitu Kegiatan awal, kegiatan inti dan kegiatan penutup. Pada kegiatan awal guru bidang studi menjelaskan model dan tujuan pembelajaran, mengingatkan siswa tentang materi yang akan diajarkan, membagi siswa kedalam 5 kelompok Inkuiri yang heterogen, aturan heterogenitas.

Kegiatan inti, yaitu pelaksanaan model pembelajaran Inkuiri diawali dengan memperkenalkan Model Pembelajaran Inkuiri kepada siswa.

Kemudian setelah selesai penjabaran materi guru dan peneliti mengarahkan siswa dalam membentuk kelompok. Dalam kegiatan kelompok guru membagikan lembar materi kepada setiap kelompok sebagai bahan yang akan dipelajari siswa

Pada kegiatan penutup guru menyimpulkan pelajaran yang telah berlangsung hari ini. memberikan tugas rumah untuk siswa. Setelah itu guru 
menginformasikan materi pelajaran yang akan dipelajari selanjutnya.

Pada pertemuan kedua diawali dengan peneliti sekilas mengulang kembali pelajaran pada pertemuan pertama dan melakukan tanya jawab tentang materi yang sudah di pelajari sebelumnya. Kemudian dilanjutkan kegiatan atau tahapan seperti pada pertemuan pertama. Pada pertemuan kedua ini siswa sudah mulai mengerti tentang bagaimana model pembelajaran Inkuiri. Siswa mulai untuk memberikan tanggapan-tanggapan mereka.

\subsubsection{Pengamatan}

Kegiatan observasi dilaksanakan selama proses belajar mengajar berlangsung. Selama observasi, peneliti mencatat kegiatan proses pembelajaran yang berlangsung dan memilai hasil tindakan.

Tabel 2. Hasil Observasi Aktivitas Siswa dalam Proses Mengajar Siklus I

\begin{tabular}{|c|c|c|c|c|}
\hline $\begin{array}{l}\mathbf{N} \\
\mathbf{O}\end{array}$ & $\begin{array}{c}\text { Rentang } \\
\text { Nilai }\end{array}$ & $\begin{array}{c}\text { Jumlah } \\
\text { Siswa }\end{array}$ & $\begin{array}{c}\text { Persen } \\
\text { tase }\end{array}$ & $\begin{array}{l}\text { Kate } \\
\text { gori }\end{array}$ \\
\hline 1 & $75-100$ & 8 & $26,67 \%$ & $\begin{array}{c}\text { Sangat } \\
\text { Aktif }\end{array}$ \\
\hline 2 & $65-74$ & 10 & $33,33 \%$ & Aktif \\
\hline 3 & $55-64$ & 12 & $40 \%$ & $\begin{array}{c}\text { Cukup } \\
\text { Aktif }\end{array}$ \\
\hline 4 & $0-54$ & 0 & $0 \%$ & $\begin{array}{l}\text { Tidak } \\
\text { Aktif }\end{array}$ \\
\hline
\end{tabular}

Keterangan :

75-100 = Sangat Aktif

65-74= Aktif

55-64= Cukup Aktif

0-54= Tidak Aktif

Dari data hasil observasi terhadap aktivitas belajar siswa terdapat empat aspek yang dinilai kepada 30 siswa, dimana siswa yang memperoleh katagori Kurang Aktif tidak ada, Cukup Aktif 12 orang, Aktif 10 orang dan katagori Sangat Aktif belum 8 orang. Sesuai dengan data tersebut maka aktivitas siswa dapat dikatakan sudah berhasil, tetapi mayoritas siswa masuk dalam kategori Cukup Aktif dan belum diketahui apakah aktivitas siswa masih akan meningkat, sehingga penelitaian dilanjutkan ke siklus II dengan menerapkan model pembelajaran Inkuiri dan memperhatikan kelemahan yang terjadi selama pelaksanaan siklus I.

Tabel 3. Hasil Belajar Siswa Siklus I

\begin{tabular}{ccccc}
\hline $\begin{array}{c}\text { N } \\
\text { O }\end{array}$ & $\begin{array}{c}\text { Rentang } \\
\text { Nilai }\end{array}$ & $\begin{array}{c}\text { Jumlah } \\
\text { Siswa }\end{array}$ & $\begin{array}{c}\text { Persen } \\
\text { tase }\end{array}$ & Ket \\
\hline & $90-100$ & - & $0 \%$ & $\begin{array}{l}\text { Sangat } \\
\text { Kom } \\
\text { peten }\end{array}$ \\
& & & $16,67 \%$ & $\begin{array}{l}\text { Kom } \\
\text { peten }\end{array}$ \\
2 & $80-89$ & 5 & $83,33 \%$ & $\begin{array}{l}\text { Cukup } \\
\text { Kom } \\
\text { peten } \\
\text { Tidak } \\
\text { Kom } \\
\text { peten }\end{array}$ \\
& $70-79$ & 25 & & \\
4 & & & $0 \%$ &
\end{tabular}

Dari data hasil belajar siswa terdapat empat kriteria penilaian kepada 30 siswa, dimana siswa yang memperoleh kategori tidak kompeten tidak ada, kurang kompeten sebanyak 25 siswa, untuk kategori kompeten 5 siswa dan sangat kompeten tidak ada.

\subsubsection{Refleksi}

Berdasarkan data hasil pengamatan pada siklus I menunjukkan bahwa terdapat $40 \%$ aktivitas siswa tergolong dalam kategori kurang aktif dan hasil belajar siswa terdapat $83 \%$ dalam kategori cukup kompeten, belum memenuhi target syarat yang diharapkan. Hal ini disebabkan oleh pada saat proses pembelajaran berlangsung guru kurang mendapatkan perhatian dari siswa dikarenakan guru tidak tepat memberikan statement yang benar untuk membuat siswa lebih tertarik dengan cara belajar menggunakan model pembelajaran Inkuiri, dan guru kurang membina hubungan yang lebih responsif dengan siswa, sehingga siswa kurang tertarik untuk mengikuti pembelajaran tersebut.

Untuk mengatasi masalah di atas dilakukan upaya sebagai berikut:

a. Peneliti menjelaskan kembali langkahlangkah model pembelajaran kepada guru.

b. Peneliti dan guru menyusun kembali RPP untuk siklus II. 
c. Guru mencoba membina hubungan yang lebih responsif kepada siswa, dan menjadikan siswa sebagai subjek yang lebih aktif dalam proses pembelajaran.

Sesuai dengan data tersebut di atas maka hasil belajar siswa dapat dikatakan kurang berhasil sehingga penelitian dengan menerapkan pembelajaran Inkuiri perlu dilanjutkan ke siklus berikutnya.

\subsection{Siklus II}

\subsubsection{Perencanaan}

Sesuai dengan hasil refleksi pada siklus pertama, bahwa aktivitas dan hasil belajar belum mengalami ketuntasan maka perlu dilakukan siklus kedua. Untuk tahap perencanaan dilakukan hal-hal sebagai berikut:

a. Untuk mengembangkan pemikiran siswa, guru memberikan ilustrasi yang bersifat memotivasi siswa.

b. Guru memberikan perhatian kepada siswa yang dirasa belum sepenuhnya dapat mengikuti model pembelajaran dengan cara memberikan penjelasan dan pengertian yang dapat membantu siswa tersebut dalam ketertinggalannya.

c. Memberikan nilai tambahan bagi siswa yang menjawab pertanyaan dengan benar, dan bagi siswa yang memberikan tanggapan terhadap pelajaran yang sedang berlangsung.

\subsubsection{Pelaksanaan}

Dalam pelaksanaan tindakan pada siklus kedua ini, berlangsung dengan durasi waktu $4 \times 45$ menit ( $2 \times$ pertemuan). Pada pertemuan pertama siklus kedua ini diawali dengan materi Sistem Perpipaan. Kegiatan pada pelaksanaan siklus kedua ini mengalami banyak kemajuan dibandingkan dengan siklus pertama, dikarenakan siswa yang semakin tebiasa dengan model pembelajaran Inkuiri.

\subsubsection{Pengamatan}

Kegiatan observasi dilaksanakan selama proses belajar mengajar berlangsung. Selama observasi, peneliti mencatat kegiatan proses pembelajaran yang berlangsung dan menilai hasil tindakan.
Dari hasil belajar siswa yang diperoleh siswa pada waktu pelaksanaan tindakan selesai maka diketahui nilai hasil belajar siswa siklus II dengan kategori tidak kompeten tidak ada, kategori kurang kompeten 2 (6,67 \%) orang, kategori kompeten 12 orang $(40 \%)$ dan kategori sangat kompeten sebanyak 16 (53,33\%) orang. Sesuai dengan data tersebut di atas maka hasil belajar siswa dapat dikatakan sudah meningkat, dan penelitian siklus berikutnya tidak perlu dilanjutkan lagi.

\subsubsection{Refleksi}

Berdasarkan hasil pengamatan selama proses belajar mengajar pada siklus II ini, dapat dilihat bahwa aktivitas dan hasil belajar siswa mengalami peningkatan, hampir semua siswa telah terbiasa dengan kondisi belajar dengan menggunakan Model Pembelajaran Inkuiri. Pada siklus II ini, dapat dilihat dari aktivitas belajar siswa dalam proses belajar mengajar sudah mengarah kepada pembelajaran yang lebih baik. Siswa telah mampu untuk membangun kerjasama dengan kelompok belajarnya.

Tabel 4. Indikator Keberhasilan Aktivitas Belajar Siswa

\begin{tabular}{ccccccc}
\hline \multirow{2}{N}{} & $\begin{array}{c}\text { Ren } \\
\text { tang }\end{array}$ & \multicolumn{2}{c}{ Siklus I } & \multicolumn{2}{c}{ Siklus II } & \\
$\mathbf{O}$ & Nilai & Fo & $\begin{array}{c}\text { Fr } \\
\mathbf{( \% )}\end{array}$ & Fo & $\begin{array}{c}\text { Fr } \\
\mathbf{( \% )}\end{array}$ & Keterangan \\
\hline 1 & $75-100$ & 8 & 26,67 & 17 & 56,67 & Sangat Aktif \\
2 & $65-74$ & 10 & 33,33 & 11 & 36,66 & Aktif \\
3 & $55-64$ & 12 & 40 & 2 & 6.67 & Cukup Aktif \\
4 & $0-54$ & 0 & 0 & 0 & 0 & Tidak Aktif \\
& & & & & & \\
\hline & Total & $\mathbf{3 0}$ & $\mathbf{1 0 0}$ & $\mathbf{3 0}$ & $\mathbf{1 0 0}$ &
\end{tabular}

Tabel 5. Indikator Keberhasilan Aktivitas Belajar Siswa

\begin{tabular}{|c|c|c|c|c|c|c|}
\hline \multirow[b]{2}{*}{$\begin{array}{l}\mathbf{N} \\
\mathbf{O}\end{array}$} & \multirow{2}{*}{$\begin{array}{c}\text { Ren } \\
\text { tang } \\
\text { Nilai }\end{array}$} & \multicolumn{2}{|c|}{ Siklus I } & \multicolumn{2}{|c|}{ Siklus II } & \multirow{2}{*}{$\begin{array}{c}\text { Ketera } \\
\text { ngan }\end{array}$} \\
\hline & & Fo & $\begin{array}{l}\text { Fr } \\
(\%)\end{array}$ & Fo & $\begin{array}{l}\mathrm{Fr} \\
(\%)\end{array}$ & \\
\hline 1 & $90-100$ & - & 0 & 16 & 53,33 & $\begin{array}{l}\text { Sangat } \\
\text { Kom } \\
\text { peten }\end{array}$ \\
\hline 2 & $80-89$ & 5 & 16,67 & 12 & 40 & $\begin{array}{l}\text { Kom } \\
\text { peten }\end{array}$ \\
\hline 3 & $70-79$ & 25 & 83,33 & 2 & 6,67 & $\begin{array}{l}\text { Cukup } \\
\text { Kom } \\
\text { peten }\end{array}$ \\
\hline
\end{tabular}




\begin{tabular}{cccccc}
$4 \begin{array}{l}<0 \\
4\end{array}$ & - & 0 & - & 0 & $\begin{array}{l}\text { Tidak } \\
\text { Kom } \\
\text { peten }\end{array}$ \\
\hline Total & $\mathbf{3 0}$ & $\mathbf{1 0 0}$ & $\mathbf{3 0}$ & $\mathbf{1 0 0}$ & \\
\hline
\end{tabular}

Hal ini membuktikan bahwa siklus selanjutnya tidak perlu dilakukan lagi. Oleh karena itu penerapan model pembelajaran Inkuiri dapat meningkatkan aktivitas dan hasil belajar Ilmu Bangunan Gedung siswa Kelas X Program Keahlian Teknik Gambar Bangunan SMK Negeri 1 Balige.

\subsection{Pembahasan Hasil Penelitian}

Berdasarkan uraian di atas, dapat dikemukakan bahwa salah satu ciri khas Penelitian Tindakan Kelas (PTK) adalah adanya siklus-siklus yang merupakan suatu proses pemecahan menuju praktek pembelajaran yang lebih baik.

Dengan perencanaan ulang serta perbaikan yang telah dilakukan, pada siklus II aktivitas dan hasil belajar siswa mengalami peningkatan. Hal ini dapat dilihat dari perubahan aktivitas siswa dalam Kategori tidak aktif tetap, kategori kurang aktif dari 12 orang menjadi 2, kategori aktif dari 10 orang menjadi 11 orang dan kategori sangat aktif dari 8 orang menjadi 17 orang. Sedangkan untuk hasil belajar siswa dalam kategori Tidak kompeten tetap, kategori Cukup Kompeten dari 25 orang menjadi 2 orang, kategori Kompeten dari 5 orang menjadi 12 orang dan kategori Sangat Kompeten dari 0 orang menjadi 16 orang. Sehingga penerapan model pembelajaran Inkuiri dapat meningkatkan aktivitas dan hasil belajar Ilmu Bangunan Gedung siswa kelas X Program keahlian Teknik Gambar Bangunan SMK Negeri 1 balige.

\section{Kesimpulan, Implikasi dan saran \\ 5.1 Kesimpulan}

Dari hasil analisis data dan pembahasan maka dapat diambil kesimpulandari penelitian, yaitu:

a. Penerapan Model Pembelajaran Inkuiri dapat meningkatkan aktivitas siswa pada mata pelajaran Ilmu Bangunan Gedung. Hal ini dapat dilihat dari perolehan nilai aktivitas siswa pada siklus I ke siklus II dengan penilaian kategori Kurang Aktif tetap 0, kategori Cukup Aktif dari 12 orang menjadi 2 orang, kategori Aktif dari 10 orang menjadi 11 orang dan kategori Sangat Aktif dari 8 menjadi 17 orang.

b. Penerapan Model Pembelajran Inkuiri dapat meningkatkan hasil belajar siswa pada mata pelajaran Ilmu Bangunan Gedung. Hal ini dapat dilihat dari peningkatan nilai siswa dari siklus I ke siklus II dengan kategori Tidak Kompeten tetap 0, kategori Cukup Kompeten dari 25 orang menjadi 2 orang, kategori Kompeten dari 5 orang menjadi 12 orang dan kategori Sangat Kompeten dari 0 menjadi 16 orang.

\subsection{Implikasi}

Berdasarkan hasil penelitian dan kesimpulan penelitian diberikan implikasi sebagai berikut:

a. Dengan diterimanya hipotesis pertama, maka perlu menjadi bahan pertimbangan bagi pihak sekolah maupun guru dalam menerapkan Model Pembelajaran Inkuiri untuk meningkatkan aktivitas siswa pada mata pelajaran Ilmu Bangunan Gedung.

b. Dengan diterimanya hipotesis kedua, maka perlu menjadi pertimbangan bagi pihak sekolah maupun guru dalam menerapkan Model Pembelajaran Inkuiri untuk meningkatkan hasil belajar siswa pada mata pelajaran Ilmu Bangunan Gedung.

\subsection{Saran}

Berdasarkan kesimpulan di atas, maka disarankan beberapa hal sebagai berikut:

a. Sebaiknya guru mengembangkan pemikiran siswa sebelum memulai suatu materi pelajaran.

b. Guru sebaiknya memberikan nilai tambahan kepada siswa yang mengajukan pertanyaan, menjawab pertanyaan, dan memberikan tanggapan selama proses belajar mengajar, karena dapat memotivasi siswa agar lebih aktif.

c. Bagi para guru, khususnya mata pelajaran Ilmu Bangunan Gedung, sebaiknya menerapkan model pembelajaran Inkuiri untuk meningkatkan aktivitas dan hasil belajr siswa. 


\section{Penerapan Model Pembelajaran Inovatif Tipe Inkuiri Untuk Meningkatkan Aktivitas dan Hasil Belajar Ilmu Bangunan Gedung Siswa Kelas x Program Keahlian Teknik Gambar Bangunan SMK Negeri 1 Balige}

\section{Daftar Pustaka}

Abdullah, 2013. Penerapan Pembelajaran Model Inkuiri Terhadap Hasil Belajar Pada Mata Diklat Dasar Elektronika Siswa Kelas X Jurusan Audio Video (AV) di SMK Negeri 1 Pangkatan Kabupaten Labuhan Batu T.P 2013/2014, Skripsi FT, UNIMED : Medan

Arikunto, Suharsimi. 2009. Dasar-dasar Evaluasi Pendidikan. Jakarta: Bumi Aksara.

Arikunto, Suharsimi. 2010. Prosedur Penelitian Suatu Pendekatan Praktik. Jakarta: Rineka Cipta.

Arikunto Suharsimi,dkk. 2009. Penelitian Tindakan Kelas. Jakarta: Bumi Aksara.

Djamarah, dkk. 2008. Strategi Belajar Mengajar. Jakarta : Rineka Cipta

Hamalik, O. 2009. Proses Belajar Mengajar. Jakarta : Bumi Aksara.

Istarani. 2011. 58 Model Pembelajaran Inovatif. Medan : Media Persada

Jamiah, Y. 2013. Peningkatan Aktivitas Belajar Siswa kelas VII SMP Pada Bilangan Pecahan dengan Teori Bruner

(Online).(http:/ / download.portalgaruda. org/article.php?article $\equiv 130015 \&$ val $\equiv 2338$ \&title=PENINGKATAN\%20AKTIVITAS $\%$ 20BELAJAR $\%$ 20SISWA $\% 20$ KELASVII $\%$ 20SMP\%20PADA\%20BILANGAN\%20PE CAHAN\%DENGAN\%20TEORI\%20BRU NER, diakses 6 April 2015)

Riyanto, Yatim. Paradigma Baru Pembelajaran. Jakarta: Departemen Pendidikan Nasional.

Rusman. 2012. Model-model Pembelajaran Mengembangkan Profesionalisme Guru. Depok: RajagrafindoPerkasa

Sardiman. 2009. Interaksi dan Motivasi Belajar Mengajar. Jakarta : Raja Grafindo Persada.

Setiawan Deny. 2013. Metode Penelitian Teknik Penulisan Skripsi. Medan: UNIMED

Slameto. 2003. Belajar dan Faktor-faktor yang Mempengaruhinya. Jakarta : Rineka Cipta.

Sudjana, N. 2009. Penilaian Hasil Proses Belajar Mengajar. Bandung: Remaja Rosdakarya.

Tamrin, A. G. 2008. Teknik Konstruksi Bangunan Gedung Sederhana Jilid 2. Jakarta : Kementrian Pendidikan Nasional Usman Ardhi, Fauzi. 2012. Aktivitas Belajar (Online),(http://eprints.uny.ac.id/8442/3 $\angle$ bab\%202.pdf, diakses 16 Juni 2014).

Winkel, W. S. 1983. Psikologi Pendidikan dan Evaluasi Belajar. Jakarta : Gramedia
Yasa. 2008. Prestasi Belajar. http://ipoteswordpress.com/2009/05/2

4. Diakses tanggal 27 Maret 2014. 